\title{
Influence of extended drought on water quality in tropical reservoirs in a semiarid region
}

Influência da estiagem prolongada na qualidade da água de reservatórios tropicais em uma região semiárida

Gustavo Girão Braga ${ }^{1}$, Vanessa Becker ${ }^{1,2}$, José Neuciano Pinheiro de Oliveira²,

Jurandir Rodrigues de Mendonça Junior ${ }^{2}$, Anderson Felipe de Medeiros Bezerra², Laíssa Macêdo Torres ${ }^{1}$, Ângela Marília Freitas Galvão² and Arthur Mattos ${ }^{2}$

${ }^{1}$ Programa de Pós-graduação em Ecologia, Universidade Federal do Rio Grande do Norte - UFRN, Av.

Senador Salgado Filho, 3000, Campus Universitário, CEP 59078-970, Natal, RN, Brazil

e-mail: gustavogbio@hotmail.com; becker.vs@gmail.com; laissa.eco@gmail.com

${ }^{2}$ Programa de Pós-graduação em Engenharia Sanitária, Departamento de Engenharia Civíl, Universidade Federal do Rio Grande do Norte - UFRN, Av. Senador Salgado Filho, 3000, Campus Universitário, CEP 59078-970, Natal, RN, Brazil

e-mail: neuciano@gmail.com; jurandirjunior.eco@gmail.com; andersonecologia@gmail.com; amfgalvaoeco@gmail.com; armattos@ct.ufrn.br

\begin{abstract}
Aim: Drought periods often occur in Brazilian semiarid region and are supposed to induce water quality degradation by changes in physical, chemical and biological properties of freshwater ecosystems. Reservoirs in this region are used as drinking-water supplies and are exposed to wide volume fluctuations during drought periods due to lack of precipitation and high evaporation rates. This study aimed to identify patterns on water quality of two reservoirs during a long drought period. It was expected that more arid and shallower conditions would favor algal growth by enhancing nutrient availability, causing a decrease on water quality. Methods: The study was based on monthly sampling over 20 months (May 2011 to December 2012) at two tropical reservoirs on Brazilian semiarid region. Precipitation and volume data were obtained from environmental agencies. Transparency was measured on field using a Secchi disk and conductivity, nutrients, suspended solids and chlorophyll- $a$ were analyzed on laboratory. Temporal changes in all environmental variables were analyzed in each reservoir using two-way cluster analysis and also principal component analysis (PCA). Results: The volume of both reservoirs decreased considerably over the study because of low or shortage of precipitation. It was possible to detect two opposite patterns of chlorophyll- $a$ in each reservoir throughout the drought season: in the first one phytoplankton growth was favored, while in the second one chlorophyll- $a$ decreased by high inorganic turbidity. Both reservoirs tended to increase their turbidity and conductivity during the drought period due to shallow conditions, which probably contributed to sediment resuspension. Conclusions: Water level reduction during the extended drought period, contributed for water quality degradation due to high algal biomass and also high turbidity found during drought period. Local factors, as the nature of suspended solids, play an important role on predicting water quality.
\end{abstract}

Keywords: eutrophic; water supply; water volume; chlorophyll- $a$; suspended solids.

Resumo: Objetivo: Períodos de estiagem são frequentes no semiárido brasileiro e parecem induzir a degradação da qualidade da água, alterando as propriedades físicas, químicas e biológicas dos ecossistemas aquáticos. Os reservatórios dessa região estão sujeitos a amplas flutuaçóes em seus volumes devido à escassez de chuvas e às altas taxas de evaporação em períodos de estiagem. O objetivo do estudo foi identificar padróes na qualidade da água de reservatórios durante um período de estiagem prolongada. Espera-se que condiçóes mais secas e rasas favoreçam o crescimento algal divido a maior disponibilidade de nutrientes, causando degradação da qualidade da água. Métodos: Foram realizadas amostragens mensais ao longo de vinte meses (maio de 2011-dezembro de 2012) em dois reservatórios tropicais do semiárido brasileiro. Dados de precipitação e volume foram obtidos por órgãos ambientais. A transparência foi medida 
em campo com disco de Secchi, enquanto que a condutividade, os nutrientes, os sólidos suspensos e a clorofila foram analisados em laboratório. As mudanças temporais nas variáveis ambientais foram analisadas em cada reservatório, utilizando uma análise de agrupamento two-way e uma análise de componentes principais (ACP). Resultados: $\mathrm{O}$ volume de ambos reservatórios reduziu consideravelmente durante o estudo devido ao período prolongado de precipitaçôes baixas ou ausentes. Foi possível identificar padrôes opostos nas concentraçôes de clorofila- $a$ dos reservatórios, à medida que a estiagem se prolongava: no primeiro o crescimento algal foi favorecido e, no segundo, a concentração de colorofila-a diminuiu devido à alta turbidez inorgânica. Ambos reservatórios apresentaram uma aumento em sua turbidez e condutividade durante o período de estiagem prolongada. Conclusóes: A redução do volume durante a estiagem prolongada contribuiu para a degradação da qualidade da água devido à alta biomassa algal e à alta turbidez. Fatores locais, como a natureza dos sólidos em suspensão, podem desempenhar um papel importante na determinação da qualidade da água desses mananciais.

Palavras-chave: eutrofização; manancial; volume; clorofila; sólidos suspensos.

\section{Introduction}

The frequency and intensity of precipitation, as well as evaporation rates can cause wide ranges in the water level of freshwater ecosystems, especially in reservoirs. Wide water volume ranges can affect physic-chemical, biological and also water quality conditions in these systems (Coops et al., 2003; Hart, 2004; Wang et al., 2012; Straškraba \& Tundisi, 2013).

Reservoirs in semiarid climates are exposed to drastic variation in water volume due to the shortage of precipitation and human demand during drought seasons (Arfi, 2003; Bouvy et al., 2003; Barbosa, et al. 2012). Previous studies have found that shallower conditions in semiarid reservoirs are associated with higher nutrient concentrations (TP and $\mathrm{NO}_{3}$ ), conductivity, turbidity and algal biomass, leading to water quality degradation and more eutrophic conditions (Naselli-Flores, 2003; Geraldes \& Boavida, 2005, 2007, Mac Donagh et al., 2009).

Eutrophic conditions can favor algal growth because of greater nutrients availability and volatile solids concentration, which by consequence, increases organic turbidity. Thus, light availability decreases by self-shading effect of phytoplankton (Agustí, 1991, Reynolds, 1999). On the other hand, algal biomass, even in rich nutrient conditions, could be decreased by high fixed suspended solids (inorganic turbidity) leading to low light availability (Kang et al., 2013). Light and nutrients could act as limiting factors on algal biomass (Reynolds, 2006).

In Brazilian semiarid region, many reservoirs are under high evaporation rates and water deficit effects, which cause significant volume reduction during drought periods (Barbosa et al., 2012). These aquatic ecosystems tend to be more stable, mixed, warm and eutrophic during low water level phase, thus favoring phytoplankton growth, as reported by Bouvy et al. (2003) and Huszar et al. (2000). Especially during extended droughts, those conditions are intensified, and toxic cyanobacterial blooms become frequent (Bouvy et al., 1999, 2000, Dantas et al., 2011).

According to that scenario, water quality tends to decrease as long as the drought season extends, causing serious impacts on regional water supplies (Huszar et al., 2000; Costa et al., 2006). Many cities and agricultural activities depend on the amount and quality of the water from these reservoirs, that is why water monitoring and management should be more constant in this region.

This study attempts to identify patterns in some water quality variables (i.e., nutrient concentration, turbidity, and $\mathrm{Chl}-a$ ) in response to large volume reductions during an extended drought. For this, water quality and local climate trends were compared between two reservoirs before and over an extended drought. We hypothesized that low water level periods are associated with water quality degradation, resulting in increased chlorophyll-a concentrations.

\section{Material and Methods}

The study was developed in two reservoirs located in the Piranhas-Açu watershed in the semiarid region of Rio Grande do Norte state (northeast, Brazil). The climate is classified as BSh or warm semiarid climate (Peel et al., 2007), with an average rainfall of $550 \mathrm{~mm}$.year ${ }^{-1}$, characterized by a rainy season between the months from February to June, and other months marked by great precipitation shortage. 
Dourado reservoir is located in Currais Novos district (Figure 1) and has a maximum volume of $10,321.600 \mathrm{~m}^{3}$, a maximum depth of $10 \mathrm{~m}$, $3.16 \mathrm{~km}^{2}$ of surface area. The other reservoir is Cruzeta, located in the Cruzeta city (Figure 1), has a maximum volume about $23,545.745 \mathrm{~m}^{3}$, maximum depth of $12 \mathrm{~m}, 8.44 \mathrm{~km}^{2}$ of surface area and a residence time of 119 days (Bezerra et al., 2014). Both reservoirs have multiple uses as fishery, irrigated agriculture, recreation, but the most important is water supply (water demands for population).

Monthly precipitation data of this period were obtained from Empresa de Pesquisa Agropecuária do Rio Grande do Norte - EMPARN by two meteorological stations in each city to evaluate precipitation patterns. Historical average rainfall values since 1963 (49 years) were also estimated to compare current values. Reservoirs volume values were monthly obtained from the local water management agency (SEMARH) and then converted to percentage values.

Water samples were monthly taken from May 2011 to December 2012 in a sampling station near to the dam, in the deepest part of the reservoir. The vertical profiles of temperature, $\mathrm{pH}$, dissolved oxygen and conductivity were measured in situ by multi-sensor probe (Hydrolab DS5) at $1 \mathrm{~m}$ intervals each from the surface to the bottom. Water transparency was estimated by the Secchi disk extinction depth. Water samples were collected with a Van Dorn bottle at different depths in epiliminion and integrated in a single sample, in which some subsamples were taken for total phosphorus, phosphate, nitrate and Chl- $a$ analyses.

In the laboratory, samples were filtered on glass fiber membranes. Soluble nutrient analyses were made using the filtrate and then measured in spectrophotometer. For the soluble reactive phosphorus (SRP) the methodology used was that proposed by Murphy \& Riley (1962) and Müller \& Wiedemann (1955) for the nitrate. One of the two membranes was used for the chlorophyll- $a$ analysis according to Jespersen \& Christoffersen (1988) while the other membrane was used in fixed and volatile suspended solids (FSS and VSS) analysis as proposed by APHA (2005).

The correlation between environmental variables was checked using simple correlation matrix. Significant differences in FSS and VSS values between the first 10 months and the last 10 months of study were checked using ANOVA one-way for each variable separately using STATISTICA ${ }^{\circledR}$ software v.7.

To verify if there were seasonal differences in the data of each reservoir during the study period, two two-way cluster analyses were used. A principal component analysis was also used for each reservoir to show how environmental variables varied during the study period. Both statistical analyses were performed using PC-ORD ${ }^{\circledR}$ v.6 software (McCune \& Mefford, 2011).

\section{Results}

According to precipitation data, 2011 was considered a rainy year with intensive rain in the first months, throughout May, June and July, followed by the usual shortage of precipitation in the rest of the year (Figure 2). In contrast, 2012 was an atypical drought year with deficit of precipitation during the rainy season (see precipitation values below the historical average among February 2012 to May 2012 in Figure 2). During the dry season in 2012
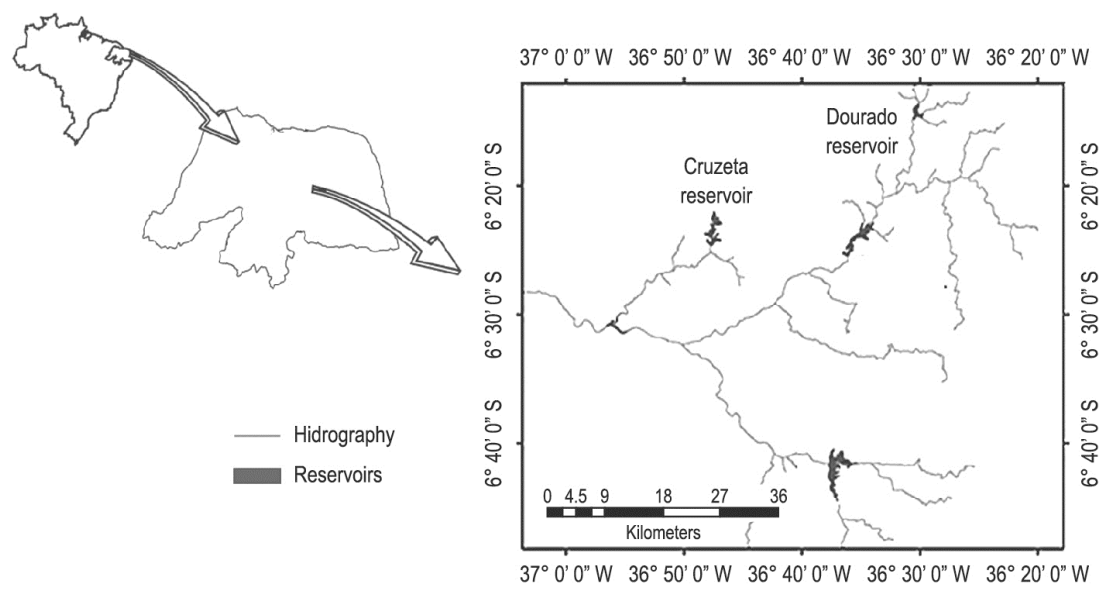

Figure 1. Location of Dourado and Cruzeta reservoirs in Rio Grande do Norte State, Brazil. 
(June 2012 to December 2012), the frequency and intensity of precipitation remained low as usual.

Maximum, minimum and mean values of limnology variables on each reservoir are presented (Table 1). The data accounts for more eutrophic conditions for Dourado reservoir (Table 1).

The initial volume of both reservoirs reduced dramatically over the study period (Figure 3 and Table 1). In the first three months, volume remained quite constant because of the rainy period and then started to decrease. Dourado and Cruzeta reservoirs remained with almost $20 \%$ of their initial volume in the end of the study period (Figure 3).

In Dourado, Chl-a started with low concentration values (May 2011 to January 2012)

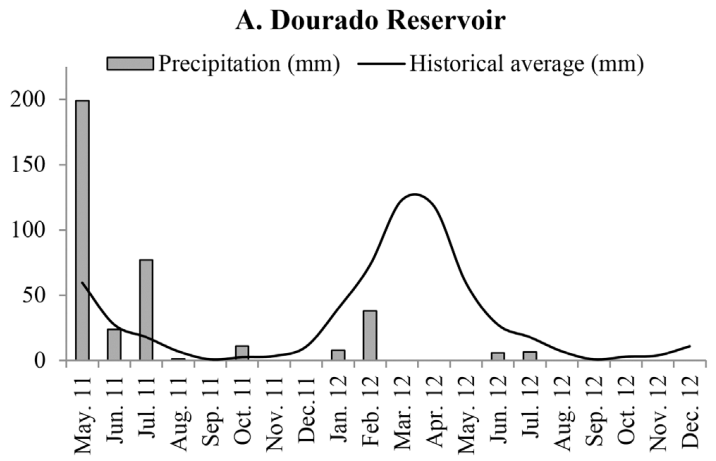

\section{B. Cruzeta Reservoir}

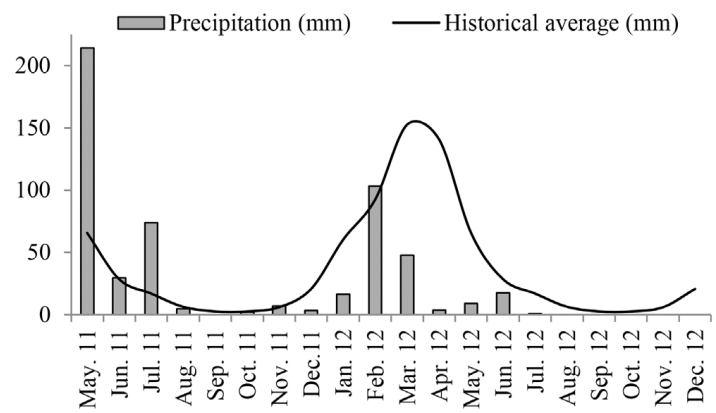

Figure 2. Precipitation in Dourado (A) and Cruzeta (B) reservoirs. The study began in the end of the rainy season when precipitation values were higher than or close to the historical average values (May-July 2011). and then increased from February 2012 reaching the maximum value of $235.04 \mu \mathrm{g} . \mathrm{L}^{-1}$ in September 2012 (Figure 3A). A different pattern was found in Cruzeta reservoir, which showed lower chlorophyll- $a$ values ranging from $3.64 \mu \mathrm{g} . \mathrm{L}^{-1}$ (September 2012) to $73.3 \mu \mathrm{g} . \mathrm{L}^{-1}$ (February 2012) (Figure 3B).

Transparency in Dourado was higher during 2011 and it tended to decrease as the drought extended in 2012 (Figure 4). Volatile suspended solids values were significantly lower during the first half of the study comparing to those found in the second part $(p=0.01)$. The same trend was found for fixed suspended solids (FSS), which showed a significant increasing between the first and the second half of the study $(p=0.003)$. In Cruzeta,

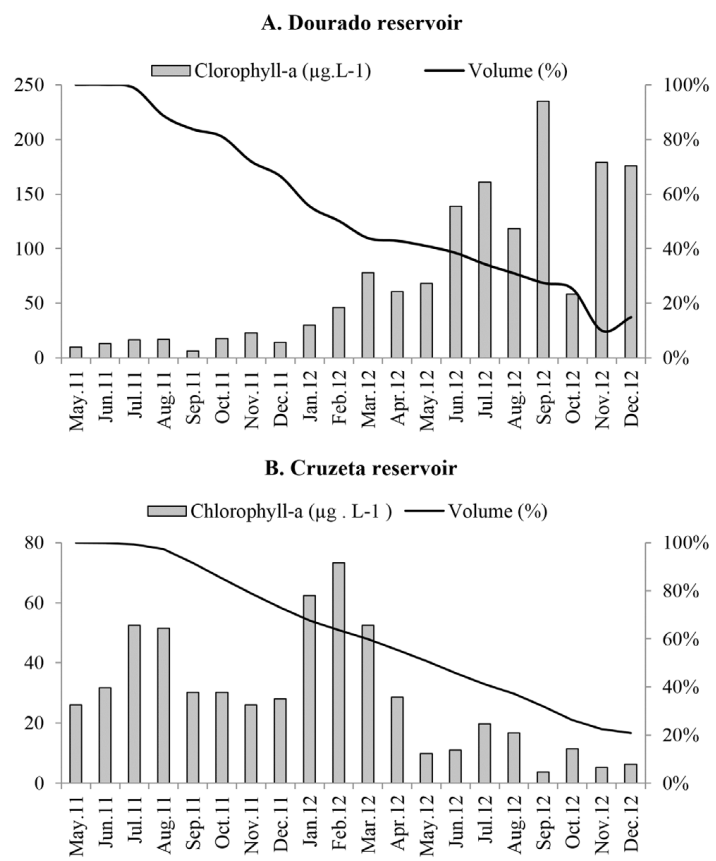

Figure 3. A. Chlorophyll- $a$ and volume variations in Dourado reservoir B. Chlorophyll- $a$ and volume variations in Cruzeta reservoir. Volume variation percentage was calculated monthly considering the initial volume as $100 \%$.

Table 1. Minimum, maximum and mean values of variables on each reservoir.

\begin{tabular}{lcccccc}
\hline \multirow{2}{*}{ Variables } & \multicolumn{3}{c}{ Dourado } & \multicolumn{3}{c}{ Cruzeta } \\
\cline { 2 - 7 } & Min. & Max. & Mean & Min. & Max. & Mean \\
\hline Volume $(\%)$ & $10 \%$ & $100 \%$ & $55 \%$ & $21 \%$ & $100 \%$ & $62 \%$ \\
Secchi Transparency $(\mathrm{m})$ & 0.2 & 1.5 & 0.7 & 0.4 & 0.9 & 0.7 \\
Conductivity $\left(\mu \mathrm{S} . \mathrm{cm}^{-1}\right)$ & 635.0 & 1786.0 & 1060.2 & 289.0 & 1070.0 & 684.8 \\
Chl- $a\left(\mu \mathrm{g} . \mathrm{L}^{-1}\right)$ & 6.1 & 235.0 & 73.4 & 3.6 & 73.3 & 28.8 \\
Nitrate $\left(\mu \mathrm{g} . \mathrm{L}^{-1}\right)$ & 54.5 & 234.0 & 116.4 & 24.5 & 212.0 & 95.6 \\
SRP $\left(\mu \mathrm{g} . \mathrm{L}^{-1}\right)$ & 0.5 & 131.0 & 24.2 & 0.0 & 64.0 & 15.4 \\
FSS & 0.0 & 8.8 & 3.7 & 0.0 & 15.2 & 5.8 \\
VSS & 0.0 & 40.8 & 12.4 & 1.2 & 12.4 & 6.9 \\
\hline
\end{tabular}




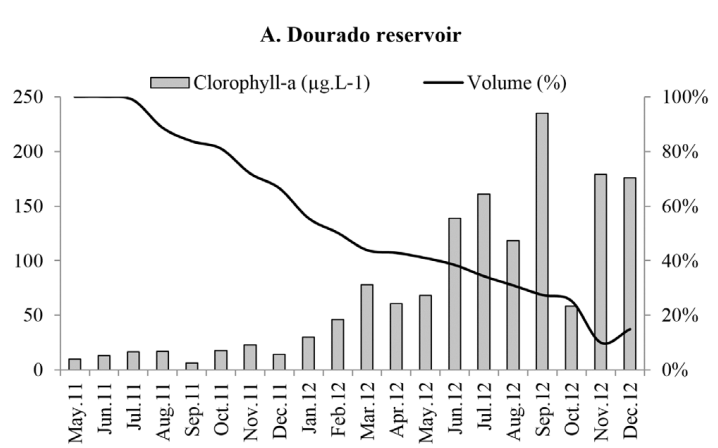

B. Cruzeta reservoir

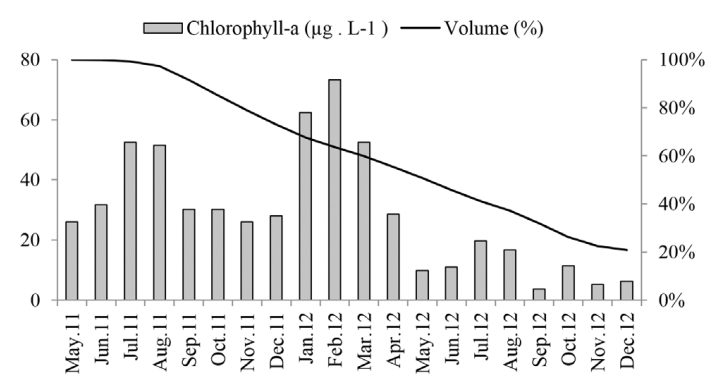

Figure 4. Secchi transparency in Dourado (grey bars) and Cruzeta (white bars) reservoirs during the study period.

VSS did not show a significant difference between the first and the second half of the study $(p=0.08)$, thus presenting a more constant pattern. In turn, FSS values showed a significant difference between of the two study periods. In this case FSS values were low during the first 10 months and higher during the last 10 .

The two-way cluster analysis shows that samples from Dourado reservoir were divided into two main groups considering around 40\% of information remaining (Figure $5 \mathrm{~A}$ ). The first cluster comprehends samples from May 2011 until April 2012 and also June 2012, these samples were grouped based on similarities, as higher precipitations, volume and transparency values, and also by low Chl- $a$, turbidity and conductivity values. Considering that, this cluster was named "Rainy and dry months". The second cluster was named "Extended drought" due to the similarities in variables found between samples May 2012 and from July 2012 to December 2012, which were associated with low volume and transparency values, while VSS, FSS and Chl- $a$ concentrations were higher (Figure 5A). Volume was positively correlated to transparency (0.93) and precipitation while negatively correlated to conductivity $(-0.88)$, Chl- $a$ (-0.82), VSS (-0.72) and FSS (-0.57).

Data from Cruzeta reservoir showed also two main clusters, but the variables were differently associated to them in the other reservoir (Figure 5A
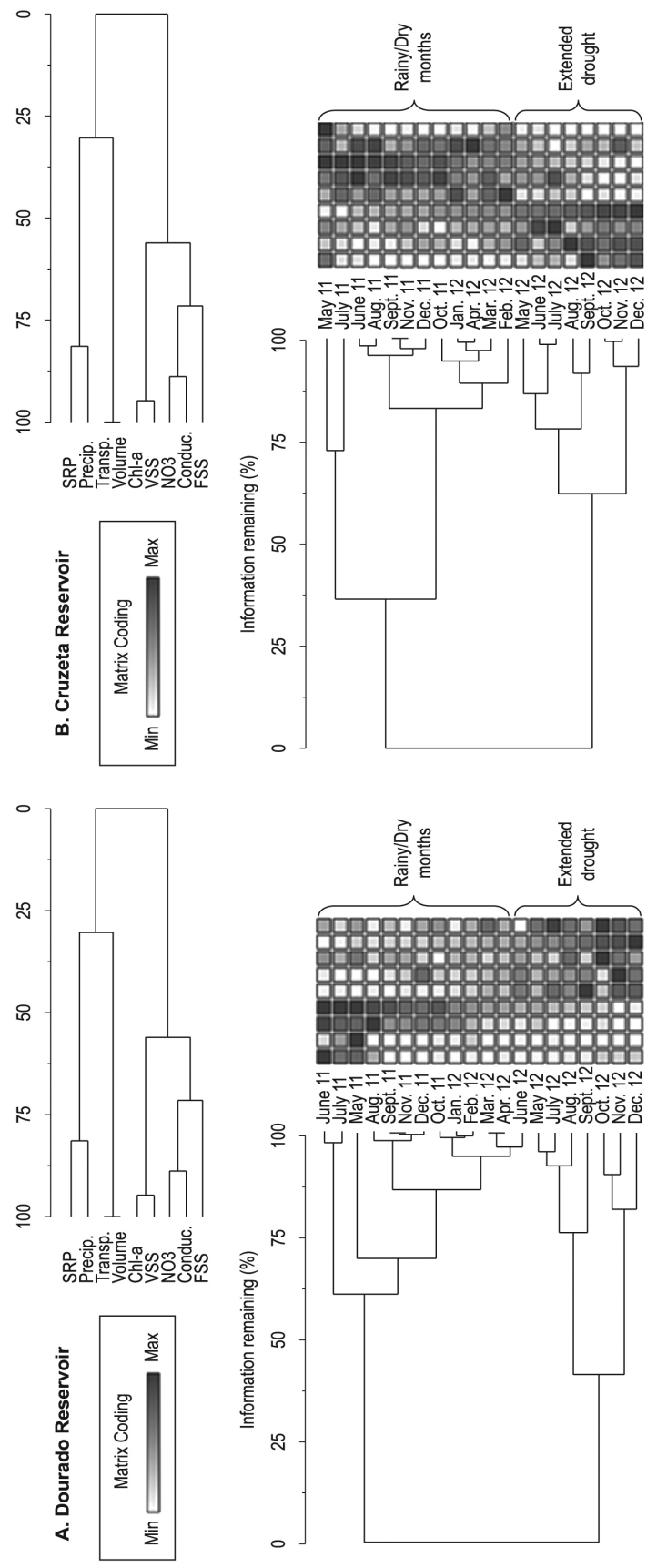

Figure 5. Two-way Cluster Analysis of Dourado (A) and Cruzeta Reservoir (B). Samples are clustered in lines while environmental variables are clustered in columns. Dark squares express maximum values of each variable while white ones represent minimum values.

and 5B). The volume was positively correlated with transparency (0.80) and Chl-a (0.59) while negatively correlated with conductivity $(-0.95)$, FSS (-0.80) and SRP (-0.55). The first main cluster, named "Rainy and Dry Months", (May 2011 to April 2012) was associated with high volumes, transparency, Chl- $a$ and negatively with 
conductivity and FSS. The second group (May 2012 to December 2012), named "Extended Drought" was associated with high inorganic turbidity (FSS) and conductivity, low volumes and less algal biomass (Figure 5B).

For Dourado the physical-chemical variables explained $77.99 \%$ of the variance in the first two axis (Axis $1=59.27 \%$ and Axis $2=18.72 \%$ ) on principal component analyses (PCA). Precipitation (0.91), volume (0.73) and transparency (0.71) were positively related to axis 1 , while Chl- $a(-0.60)$ and volatile suspended solids $(-0.84)$ were negatively related to this axis $(p=0.001)$ (Figure $6 \mathrm{~A})$. The variance in axis 2 was not significantly explained by any of the variables $(p>0.05)$.

In Cruzeta, PCA variables explained $87.43 \%$ of the variance on the first two axis (Axis $1=58.03 \%$ and Axis $2=29.40 \%$ ). This analysis also showed a different seasonal pattern in Chl-a, compared with Dourado, as explained previously in Figure 3. The precipitation (0.90), Chl- $a(0.85)$ and volume (0.81) were associated positively, while, FSS (-0.64) and conductivity $(-0.80)$ were negatively related with axis $1(p=0.01)$ (Figure $4 \mathrm{~B})$. SRP $(-0.83)$ and nitrate $(-0.65)$ were negatively correlated to axis 2 $(p=0.03)$, and were associated with "Extended Drought" samples (Figure 6B).
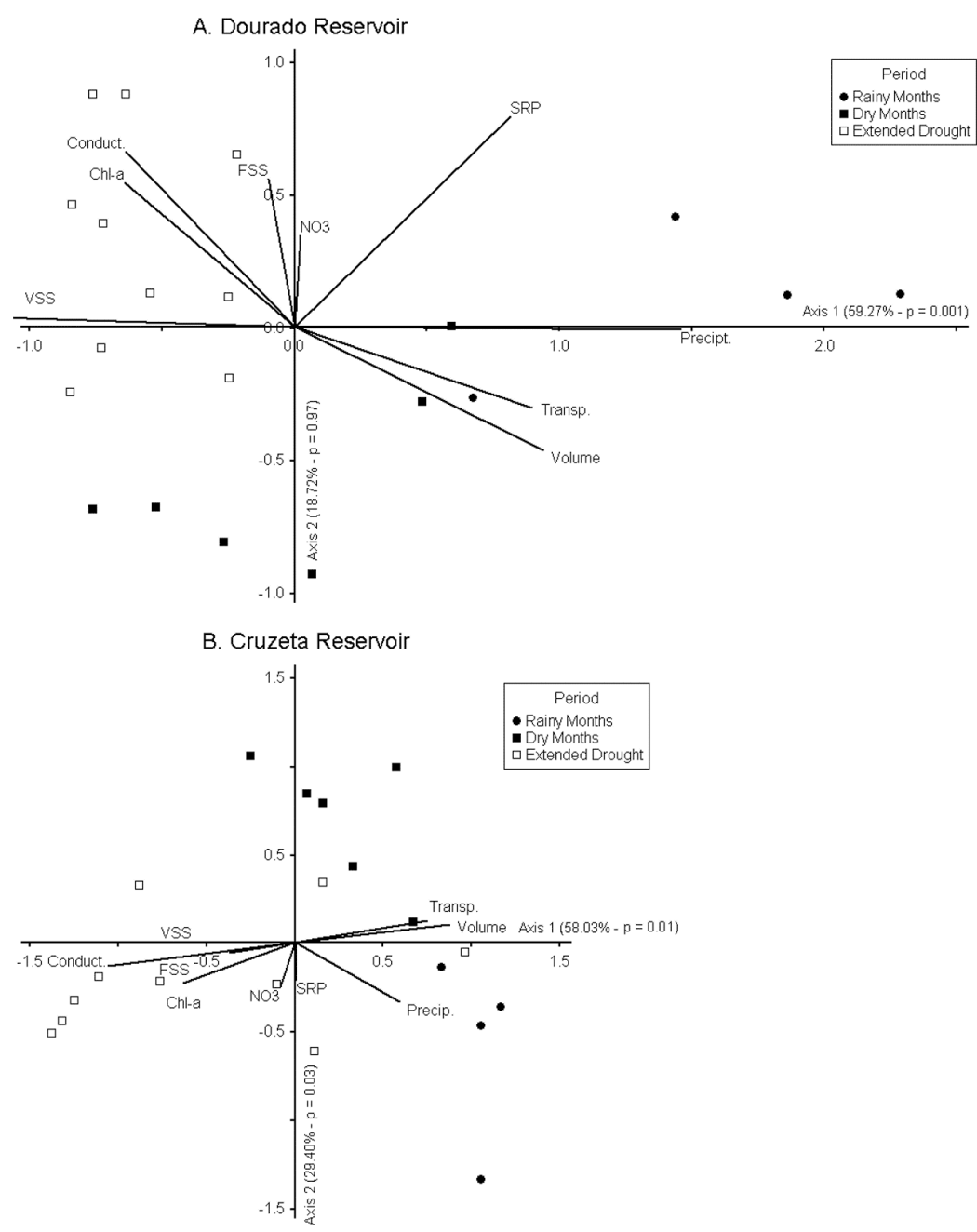

Figure 6. Principal components analysis (PCA) scores applied to environmental variables in Dourado (A) and Cruzeta (B) reservoirs. Monthly sample units were classified according to period classification (Figure 5). A. Dourado: Dark Dots and Dark squares = Rainy and Dry months (May 2011 to April 2012 and June 2012); White squares = Extended drought period (May 2012 and July 2012 to December 2012). B Cruzeta: Dark dots and Dark squares = Rainy and Dry months (May 2011 to April 2012); White squares = Extended drought period (May 2012 to December 2012) . Precip. = Precipitation; Transp. = Transparency; Conduct. = Conductivity; FSS = Fixed Suspended Solids; VSS = Volatile Suspended Solids; Chl-a = Chlorophyll- $a$; SRP = Soluble Reactive Phosphorus $\mathrm{NO}_{3}=\mathrm{Nitrate}$ 


\section{Discussion}

The indirect effects of extended dry periods on water quality were assessed by changes in $\mathrm{Chl}-a$, dissolved nutrients and transparency due to water volume reduction. Both reservoirs showed a considerable reduction in their water levels, which was followed by reduced water quality in terms of high Chl- $a$ concentrations or suspended solids. Results indicate the impacts of water level fluctuations on these aquatic ecosystems and also that inorganic suspended matter (FSS) can interfere in the dynamic of algal biomass and water quality due to light availability and turbidity.

The wide volume fluctuations in a reservoir alter water physic-chemical conditions as the mixing regime, light availability and nutrient concentrations. Those are essential driving factors for the phytoplankton growth (Reynolds, 2006). Studies showed that low water levels in semiarid regions are often associated with high algal biomass and organic turbidity in freshwater ecosystems, due to high nutrients availability for primary producers (Naselli-Flores, 2003; Geraldes \& Boavida, 2005, 2007; Bond et al., 2008).

In Dourado reservoir the maximum volume capacity during rainy months was associated with a clear water state with low phytoplankton biomass and high SRP concentration. As precipitation started to be more scarce, there was a gradual water loss, due to the intense evaporation rates, followed by an increasing in conductivity, Chl-a and VSS. Decreasing SRP values during extended drought can be explained by phytoplankton uptake (Reynolds, 2006) as showed by the increasing Chl-a pattern during the study. Similar pattern was found in Tapacurá reservoir, where low water levels periods were associated with low SRP concentration and cyanobacterial blooms (Bouvy et al., 2003). Low water levels can enhance nutrient recycling, promoting algal growth, turbidity and eutrophication in shallow freshwater ecosystems (Beklioglu, 2007). Thus, in Dourado reservoir, algal growth during extended drought was the responsible for turbid conditions (high VSS), decreasing water quality. Some studies in Brazilian semiarid reservoirs reported similar results (Bouvy et al., 2000, 2003; Huszar et al., 2000). Therefore, it means that Chl- $a$ can work as a predictor of water quality during droughts and that low water levels can be a harmful condition for this reservoir.

Cruzeta reservoir presented an opposite and unexpected pattern in algal biomass over the study period, compared to Dourado reservoir. Instead of increasing in the extended drought period, Chl- $a$ decreased as long as the water volume reduced, indicating that high algal biomass was not necessarily related to drought periods.

Environmental conditions in Cruzeta reservoir within extended drought period did not favor algal growth. It is suggested that the increasing of FSS reached high concentrations since May 2012, which could be responsible for the $\mathrm{Chl}-a$ reduction. Other fact that indicates this algal biomass crashing is the high concentrations of FSS that can cause inorganic turbidity, which can limit or decrease algal growth by shading (Reynolds, 1999, 2006), what may have occurred during this extended drought.

In Cruzeta reservoir, Freitas et al. (2011) also reported a crash in algal biomass due to inorganic turbidity. This study showed that light availability and Chl- $a$ values were lower in the end of drought period than in the rainy period, because of higher FSS values.

The high inorganic turbidity caused by FSS in Cruzeta reservoir can be explained by the shallower conditions during the drought and by its greater surface area, which together enhance sediment resuspension by the wind (Ferrão-Filho \& Esteves, 1994). It is also known that inorganic matter (FSS) represents almost $76 \%$ of the total suspended solids in this reservoir, demonstrating that high loads come from the catchment (Freitas et al., 2011). Even with low Chl-a level during the drought, High FSS values indicate water quality degradation for human consumption (Bilotta \& Brazier, 2008). In this case, FSS was a better predictor of water quality than Chl-a.

High conductivity values in both reservoirs during extended drought were already expected according to Bouvy et al. (1999), because high evaporation rates and precipitation shortage concentrate solutes in water. This seems to be a pattern in Brazilian tropical semiarid reservoirs (Barbosa et al., 2012).

According to the results, the hypothesis can be partly corroborated because Chl-a concentration present opposite patterns in both reservoirs within low volume conditions. Thus, only Dourado reservoir seems to corroborate with our hypothesis, due to the increasing Chl- $a$ over the extended drought. Despite showing a decreasing pattern in Chl- $a$, Cruzeta reservoir also suffered from water quality degradation due to high FSS levels during the extended drought. In general, drought decreases water quality by reducing water levels, but local 
factors, like FSS concentration, can also play an important role on determining which variables will be the predictors of the water quality in semiarid reservoirs.

\section{Acknowledgements}

The authors are thankful to FINEP (Financiadora de Estudos e Projetos) CNPq (Conselho Nacional de Desenvolvimento Científico e Tecnológico) and CAPES (Coordenadoria de Aperfeiçoamento de Pessoal Superior) for financial support. EMPARN and SEMARH for precipitation and volume data. The authors also are grateful to Larissa Mirelly Cavalcanti and Kátia Brandão de Miranda for technical support, Luciana de Souza Cardoso for statistical analysis; and finally to Dr. Odete Rocha for her valuable comments on the manuscript.

\section{References}

AGUSTÍ, S. Light environment within dense algal populations: cell size influences on self-shading. Journal of Plankton Research, 1991, 13(4), 863-871. http://dx.doi.org/10.1093/plankt/13.4.863.

AMERICAN PUBLIC HEALTH ASSOCIATION APHA. Standard methods for the examination of water and wastewater. Washington, 2005, $1325 \mathrm{p}$.

ARFI, R. The effect of climate and hydrology on the trophic status of Sélingué reservoir, Mali West Africa. Lakes and Reservoirs: Research and Management, 2003, 8(3-4), 247-257. http://dx.doi.org/10.1111/j.14401770.2003.00223.x.

BARBOSA, J.E.L., MEDEIROS, E.S.F.M., BRASIL, J., CORDEIRO, R.S., CRISPIM, M.C.B. and SILVA, G.H.G. Aquatic systems in semi-arid Brazil: limnology and management. Acta Limnologica Brasiliensia, 2012, 24(1), 103-118. http://dx.doi. org/10.1590/S2179-975X2012005000030.

BEKLIOGLU, M., ROMO, S., KAGALOU, I., QUINTANA, X. and BÉCARES, E. State of the art in the functioning of shallow Mediterranean lakes: workshop conclusions. Hydrobiologia, 2007, 584(1), 317-326. http://dx.doi.org/10.1007/s10750007-0577-x.

BEZERRA, A.F.M., BECKER, V. and MATTOS, A. Balanço de massa de fósforo total e o estado trófico em reservatórios do semiárido. Revista Brasileira de Recursos Hidricos, 2014, 19(2), 67-76.

BILOTTA, G.S. and BRAZIER, R.E. Understanding the influence of suspended solids on water quality and aquatic biota. Water Research, 2008, 42(12), 2849-2861. http://dx.doi.org/10.1016/j. watres.2008.03.018. PMid:18462772

BOND, N.R., LAKE, P.S. and ARTHINGTON, A.H. The impacts of drought on freshwater ecosystems: an Australian perspective. Hydrobiologia, 2008,
600(1), 3-16. http://dx.doi.org/10.1007/s10750008-9326-z.

BOUVY, M., FALCÃO, D., MARINHO, M., PAGANO, M. and MOURA, A. Occurrence of Cylindrospermopsis (Cyanobacteria) in 39 Brazilian tropical reservoirs during the 1998 drought. Aquatic Microbial Ecology, 2000, 23, 13-27. http://dx.doi. org/10.3354/ame023013.

BOUVY, M., MOLICA, R., OLIVEIRA, S., MARINHO, M. and BEKER, B. Dynamic of a toxic cyanobacterial bloom (Cylindrospermopsis raciborskii) in a shallow reservoir in the semi-arid region of northeast Brazil. Aquatic Microbial Ecology, 1999, 20, 285-297. http://dx.doi.org/10.3354/ame020285.

BOUVY, M., NASCIMENTO, S.M., MOLICA, R.J.R., FERREIRA, A., HUSZAR, V. and AZEVEDO, S.M.F.O. Limnological features in Tapacurá reservoir (northeast Brazil) during a severe drought. Hydrobiologia, 2003, 493(1-3), 115-130. http:// dx.doi.org/10.1023/A:1025405817350.

COOPS, H., BEKLIOGLU, M. and CRISMAN, T.L. The role of water-level fluctuations in shallow lake ecosystems - workshop conclusions. Hydrobiologia, 2003, 506-509(1-3), 23-27. http://dx.doi. org/10.1023/B:HYDR.0000008595.14393.77.

COSTA, I.A., AZEVEDO, S.M.F.O., SENNA, P.A., BERNARDO, R.R., COSTA, S.M. and CHELLAPPA, N.T. Occurrence of toxin-producing cyanobacteria blooms in a Brazilian semiarid reservoir. Brazilian Journal of Biology, 2006, 66(1B), 211-219. http://dx.doi.org/10.1590/S151969842006000200005. PMid:16710515

DANTAS, E.W., MOURA, A.N. and BITTENCOURTOLIVEIRA, M.C. Cyanobacterial blooms in stratified and destratified eutrophic reservoirs in semi-arid region of Brazil. Annals of the Brazilian Academy of Sciences, 2011, 83(4), 1327-1338. http:// dx.doi.org/10.1590/S0001-37652011000400019. PMid:22146960

FERRÃO-FILHO, A. and ESTEVES, F.A. Nutritive value and sedimentation rates of particulate matter in the course of two flood pulses in an Amazonian Várzea lake. Archiv fuer Hydrobiologie, 1994, 130(3), 325-337.

FREITAS, F.R.S., RIGHETTO, A.M. and ATTAYDE, J.L. Cargas de fósforo total e material em suspensão em um reservatório do semi-árido brasileiro. Oecologia Australis, 2011, 15(3), 655-665. http:// dx.doi.org/10.4257/oeco.2011.1503.16.

GERALDES, A.M. and BOAVIDA, M.-J. Seasonal water level fluctuations: Implications for reservoirs limnology and management. Lakes and Reservoirs: Research and Management, 2005, 10(1), 59-69. http:// dx.doi.org/10.1111/j.1440-1770.2005.00257.x.

GERALDES, A.M. and BOAVIDA, M.-J. Zooplankton assemblages in two reservoirs: one subjected to 
accentuated water level fluctuations, the other with more stable levels. Aquatic Ecology, 2007, 41(2), 273284. http://dx.doi.org/10.1007/s10452-006-9057-z.

HART, R.C. Cladoceran periodicity patterns in relation to selected environmental factors in two cascading warm-water reservoirs over a decade. Hydrobiologia, 2004, 526(1), 99-117. http://dx.doi.org/10.1023/ B:HYDR.0000041610.56021.63.

HUSZAR, V.L.M., SILVA, L.H.S., MARINHO, M., DOMINGOS, P. and SANT'ANNA, C.L. Cyanoprokaryote assemblages in eight productive tropical Brazilian waters. Hydrobiologia, 2000, 424(1), 67-77. http://dx.doi. org/10.1023/A:1003996710416.

JESPERSEN, A.M. and CHRISTOFFERSEN, K. Measurements of chlorophyll- $a$ from phytoplankton using ethanol as extractions solvent. Archiv fuer Hydrobiologie, 1988, 109, 445-454.

KANG, Y., SONG, X. and LIU, Z. Sediment resuspension dampens the effect of nutrient inputs on the phytoplankton community: a mesocosm experiment study. Hydrobiologia, 2013(710), 117127.

MAC DONAGH, M.E., CASCO, M.A. and CLAPS, M.C. Plankton relationships under small water level fluctuations in a subtropical reservoir. Aquatic Ecology, 2009, 43(2), 371-381. http://dx.doi. org/10.1007/s10452-008-9197-4.

MCCUNE, B. and MEFFORD, M.J. PC-ORD: multivariate analysis of ecological data. Version 6. Gleneden Beach: MjM Software Design, 2011.

MÜLLER, R. and WIEDEMANN, F. Die bestimmung des nitrats in wasser. Jahrbuch für Wasserchemie und Wasserreinigungs-technik. Renibek: Chimie, 1955, p. $247-271$.
MURPHY, J. and RILEY, J.P. A modified single solution method for the determination of phosphate in natural waters. Analytica Chimica Acta, 1962, 27, 31-36. http://dx.doi.org/10.1016/S0003-2670(00)88444-5.

NASELLI-FLORES, L. Man-made lakes in Mediterranean semi-arid climate: the strange case of Dr Deep Lake and Mr Shallow Lake. Hydrobiologia, 2003, 506-509(1-3), 13-21. http://dx.doi. org/10.1023/B:HYDR.0000008550.34409.06.

PEEL, M.C., FINLAYSON, B.L. and MCMAHON, T.A. Updated world map of the Köppen-Geiger climate classification. Hydrology and Earth System Sciences, 2007, 11(5), 1633-1644. http://dx.doi. org/10.5194/hess-11-1633-2007.

REYNOLDS, C.S. Ecology of phytoplankton. Cambridge: Cambridge University Press, 2006, 535 p.

REYNOLDS, C.S. Phytoplankton assemblages in reservoirs. In J.G. TUNDISI and M. STRAŠKRABA, orgs. Theoretical reservoir ecology and its aplications. Leiden: Backhuys, 1999, pp. 439-456.

STRAŠKRABA, M. and TUNDISI, J.G. Gerenciamento da qualidade da água de represas. São Paulo: Oficina de Textos, 2013, $300 \mathrm{p}$.

WANG, S., QIAN, X., HAN, B.P., LUO, L.C. and HAMILTON, D.P. Effects of local climate and hydrological conditions on the thermal regime of a reservoir at Tropic of Cancer, in southern China. Water Research, 2012, 46(8), 2591-2604. http://dx.doi.org/10.1016/j.watres.2012.02.014. PMid:22391017
Received: 21 February 2014 Accepted: 02 December 2014 